\title{
KULT ŚW. STANISŁAWA W DIECEZJI KRAKOWSKIEJ W ŚWIETLE PATROCINIÓW DO 1529 R.
}

Kult św. Stanisława podobnie jak kulty innych świętych badać można w wielu aspektach. Jednym z nich są patrocinia, czyli wezwania świętych patronów kościołów, kaplic, ołtarzy ${ }^{2}$. Niestety całokształt badań nad tytułami kościelnymi w Polsce nie jest imponujący, co ma swoje odniesienie do kultu św. Bisku$\mathrm{pa}^{3}$. Jak dotąd bowiem nie powstała żadna praca ujmująca wezwania krakowskiego mẹczennika w sposób wyczerpujący. Wprawdzie niemało miejsca temu zagadnieniu poświęcili na łamach swych licznych artykułów zwłaszcza ks. Kumor i ks. Schenk ${ }^{4}$, to jednak trudno uznać dotychczasowe informacje za całościowe i ostateczne ${ }^{5}$. Uwagę koncentruję na diecezji krakowskiej w jej średniowiecznych granicach.

Podstawowe znaczenie ma data kanonizacji św. Stanisława (17. IX. 1253). Stanowiła ona najważniejsze wydarzenie w dziejach jego kultu liturgicznego ${ }^{6}$. Od

${ }^{1}$ Artykuł ten jest skróconą wersją pracy magisterskiej, powstałej pod kierunkiem dr. hab. Jerzego Rajmana.

${ }^{2}$ A. G i e y s z tor, J. S z y m ań s k i, Patrocinia [w:] Stownik Starożytności Stowiańskich, pod red. G. Labudy, Z. Stiebera, t. 4/, Wrocław 1970, s. 44-46.

${ }^{3}$ Literature zestawia A. W i t k ow s ka, Titulus ecclesiae. Wezwania wspótczesnych kościotów katedralnych $w$ Polsce, Warszawa 1999, s. 12-16.

${ }^{4}$ B. K u m o r, Powstanie i rozwój sieci parafialnej w Matopolsce Poludniowej do końca XVI w., „Prawo Kanoniczne” (dalej cyt. PK), 6:1963, nr 1-4, s. 485-486; Tenże, Sieć parafialna $w$ diecezji krakowskiej w świetle Liber beneficiorum Jana Dtugosza, „Roczniki Teologiczno-Kanoniczne" (dalej cyt. RTK), 29:1982, z. 4, s. 38; W. S c h e n k, Kult świętych w Polsce. Zarys historyczny, „RTK” 13:1966, z. 4, s. 89-91; Tenże, Kult liturgiczny św. Stanistawa Biskupa na Ślasku w świetle średniowiecznych rękopisów liturgicznych. Studium historyczno-liturgiczne, Lublin 1959 , passim; Tenże, Liturgiczny kult św. Stanisława Biskupa w Polsce, „Analecta Cracoviensia” (dalej cyt. AC), 11:1979, s. 587-601.

${ }^{5}$ Dane odnoszą się głównie do średniowiecznej diecezji wrocławskiej. - W. S c h e n k, Kult liturgiczny, passim; J. R a j m a n, Pogranicze ślasko-matopolskie w średniowieczu, Kraków 1998, s. 257; - Dla diecezji krakowskiej posiadamy dane dotyczące parafii jedynie z Południowej Małopolski: B. Ku mor, Powstanie $i$ rozwój, s. 485-486, oraz tabelaryczne zestawienia parafii: D. Szy mańs ki, Wezwania kościotów parafialnych $w$ diecezji krakowskiej $w$ końcu XVI w., „Roczniki Humanistyczne” (dalej cyt. Roczn. Hum.), 41:1993, z. 2, passim.

${ }^{6} \mathrm{Z}$ bogatej literatury poświęconej kultowi liturgicznemu zob.: S. B e ł c h, Święty Stanistaw patron Polaków, Londyn 1978, J. R a j ma n, Przedkanonizacyjny kult św. Stanistawa biskupa, 
tego momentu mówić też można o jego patrociniach. Chcąc prześledzić natężenie kultu w tym aspekcie nic można zapominać o potrzebie ustalenia w miarę dokładnej liczby kościołów znajdujących się na obszarze biskupstwa krakowskiego. Bez tego uzyskany obraz wezwań byłby niemiarodajny.

Szczegółowe badania pozwoliły ustalić przybliżoną liczbę obiektów sakralnych, funkcjonujących w diecezji krakowskiej ok. 1529 r. Łączna liczba kościołów wszystkich typów wynosiła przynajmniej 1004 ( w tym 852 parafie, 47 kaplic szpitalnych, 37 świątyń klasztornych, 42 kościoły krakowskie, oraz 26 kościołów miejskich) ${ }^{7}$. Do liczb tych będę odnosił uzyskany obraz wezwań św. Biskupa. Kolcjne wywody poświęcam przedstawieniu szczegółowych informacji o chronologii i liczebności obiektów sakralnych dedykowanych patronowi Królestwa Polskiego w latach 1253-1529.

Charakterystykę kultu rozpocząć należy od Krakowa, a więc miejsca w którym się zrodził i skąd promieniował na całą Polskę. To właśnie tutaj znajdowały się jego śmiertelne szczątki, tutaj powstały żywoty, notowano cuda i czyniono starania o kanonizację. Wśród 42 świątyń św. Stanisław współpatronował zaledwie dwóm? . Był to kościół skałeczny oraz katedra wawelska. Kościół św. Michała Archanioła na Skałce należy do najstarszych świątyń Krakowa, czego dowodem może być patrocinium ${ }^{10}$. Z miejscem tym tradycja połączyła męczeńską śmierć św. Stanisława, zamordowanego z rozkazu króla Bolesława Śmiałego (8) 11. IV. 1079 r. Potwierdzeniem tej wczesnej i zarazem mocno ugruntowanej tradycji jest fakt iż niebawem po kanonizacji kościół św. Michała otrzymał drugie wezwanie. Stało się to w latach 1254-1270. Rocznik Traski odnotował bowiem pod 1270 r. wielki wylew Wisły, który sięgnął do Góry św. Stanisława, czyli Skałki ${ }^{11}$. Mimo, że już w 1088 r. dokonano translacji (przeniesienia) zwłok biskupa do katedry, Skałka nadal otaczana była powszechną czcią wiernych i pozo-

„Nasza Przeszłość” (dalej cyt. „NP.”), 80:1993, s. 5-49; Z. S u 1 o w s k i, Z. W i k t o r z a k, Stanisław ze Szczepanowa [w:] Hagiografia polska. Słownik bio- i bibliograficzny, t. 2, Poznań 1972, s. $435-455$.

${ }^{7}$ Szerzej kwestie związane z badaniem stanu sieci kościelnej omawiam w artykule Sieć kościelna diecezji krakowskiej na przetomie XV/XVI w. na tle jej rozwoju od poczq̨tków XIV w., „Teki Krakowskie", 12:2000, s. 135-143, tam też szczegółowa literatura przedmiotu.

${ }^{8}$ Datę początkową wyznaczają krakowskie uroczystości pokanonizacyjne z roku 1254. J. D ł u g o s z, Vita sanctissimi Stanislai Cracoviensis episcopis, wyd. J. Polkowski, J. Pauli Żegota, t. 1, Lwów 1887, s. 149-151, badania kończę zaś na 1529 r. Wstęp do Księgi dochodów beneficjów kościelnych diecezji krakowskiej z roku 1529 (tzw. Liber Retaxationum), wyd. Z. LeszczyńskaSkrętowa, Wroclaw 1968 (dalej cyt. $L R$ ).

${ }^{9}$ Brak całościowego spojrzenia na miejsce Krakowa w dziejach kultu. Podstawowa literatura: A. W i t k o w s a , Kulty patnicze piętnastowiecznego Krakowa. Z badań nad miejska kulturq religijna, Lublin 1984, passim, oraz S. D z i w i s z, Kult św. Stanistawa Biskupa w Krakowie do soboru trydenckiego, Kraków 1979 (maszynopis bez sygn. w Archiwum Papieskiej Akademii Teologicznej w Krakowie).

${ }^{10} \mathrm{~J}$. Kło c z o w sk i, Kult św. Michała Archanioła w Polsce średniowiecznej, „Zeszyty Naukowe KUL", 14:1971, z. 4, s. 21. Szczegołową literaturę zestawiają M. K ra s n o w ols k a i I. K m i e to w i c z-D ra thowa, Krakowska Skatka: topografia i zabudowa, ,Studia Claromontana" (dalej cyt. SC), 17:1997, s. 202.

${ }^{11}$ Rocznik Traski, [w:] Monumenta Poloniae Historica (dalej cyt. MPH) t. 2, Lwów 1872, s. 841. 
stawała najważniejszym centrum pielgrzymkowym ${ }^{12}$. Najbardziej znaną była piesza pielgrzymka ekspiacyjna królów polskich w wigilię obrzędów koronacyjnych. Pierwszy odbył ją Władysław Warneńczyk w $1434 \mathrm{r}$. Sanktuarium skałeczne od 1472 r. znajdowało się pod troskliwą opieką zakonu paulinów, sprowadzonego tutaj przez Jana Długosza ${ }^{13}$. W 1505 r. ukończono budowę kaplicy dedykowanej Biskupowi. Jej początki sięgają być może 1441 r. $^{14}$

Wspomniana translacja uczyniła $\mathrm{z}$ wawelskiej katedry główny ośrodek kultu św. Stanisława. Ogniskował się on przy jego grobie. Oficjalny kult relikwii zapoczatkowały obchody kanonizacyjne z 8 maja 1254 r. Podczas tych uroczystości relikwie Biskupa złożono na ołtarzu św. Floriana ${ }^{15}$. Odtąd ołtarz ten dedykowano św. Stanisławowi. W ciaggu następnych stuleci o urządzenie ołtarza-grobu dbali polscy monarchowie. Składano przy nim liczne wota, w tym trofea wojenne. Najcenniejszą pamiątka było kilkadziesiąt choragwi krzyżackich, zdobytych pod Grunwaldem $^{16}$. Po kanonizacji św. Biskup obrany został na współpatrona katedry. Z zasady bowiem patronowi kościoła poświęcano ołtarz główny ${ }^{17}$. Po raz pierwszy pojawia się $\mathrm{w}$ tej roli $\mathrm{w}$ dokumencie papieskim z $1256 \mathrm{r}$, nadającym kościołowi katedralnemu odpusty w święto jego translacji ${ }^{18}$. Wzmianka z $1258 \mathrm{r}$. rejestruje także tytuł św. Wacława, tak więc pierwotne wezwanie nie uległo zapomnieniu ${ }^{19}$.

Patrocinia św. Stanisława odnotowano w innych światyniach krakowskich. W kościele mariackim kaplice $(1383 \mathrm{r} \text {. })^{20}$, oraz dwa ołtarze, wzmiankowane odpowiednio w 1433 i $1481 \mathrm{r}^{21}$ Altarie znajdowały się także w kościele św. Barbary (1443), oraz dominikańskim pod wezwaniem Św. Trójcy $(1447)^{22}$.

${ }^{12}$ Szerzej kwestie związane z translacją porusza Rajman, jw., s. 9-22; por. W i t k o w s k a, Kulty..., s. 83 .

${ }^{13}$ W. S c h e n k, Pielgrzymki Polaków do sanktuariów maryjnych $i$ świętych Pańskich (X$-X V I$ wiek), „Częstochowskie Studia Teologiczne", 7:1979, s. 251.

${ }^{14}$ K. S z a fra n i e c, Fundacja Paulinów na Skatce, „S.C.” 17:1997, s. 307-327. Wśród licznych przedsięwzięć dziejopisa na uwagę zasługuje także niedoszła do skutku fundacja klasztoru kartuzów. Długosz zamierzał poświęcić pustelniczy klasztor w podkrakowskich Bielanach Najśw. Maryi Pannie i św. Stanisławowi. Szerzej F. S ikora, O fundacji kartuskiej Jana Dlugosza, „Kwartainik Historyczny”, 80:1973, nr 4, s. 872-885.

${ }^{15}$ K. D o brow ols k i, Dzieje kultu św. Floriana w Polsce do polowy XVI w., Warszawa 1923, s. 8-13.

${ }^{16}$ T. W o j c i e c h o w s ki, Kościól katedralny w Krakowie, Kraków 1900, passim.

${ }^{17}$ S. D z i w i s z, Kult..., s. 119; W. S c h e n k, Ottarze. Liturgiczny kult, s. 599.

${ }^{18}$ Bullarium Poloniae, t. 1, wyd. I. Sułkowska-Kuras, S. Kurass, Rzym-Lublin 1982, nr 597 (dalej cyt. BP). O wczesnej datacji świadczy także umieszczenie na fasadzie katedry rzeźby Biskupa, datowanej na druga połowę XIII lub początek XIV w.; - T. D o b row ol s k i, Sztuka Krakowa, Kraków 1964, s. 108; A. W i t k o w s k a, Titulus, s. 217.

${ }^{19}$ Kodeks dyplomatyczny katedry krakowskiej św. Wactawa, t. 1, wyd. F. Piekosiński, Kraków 1874 (dalej cyt. $K D K$ ), nr 59.

${ }^{20}$ Kodeks dyplomatyczny miasta Krakowa, t. 2, wyd. F. Piekosiński, Kraków 1883, nr 393.

${ }^{21}$ Zbiór dokumentów katedry $i$ diecezji krakowskiej, t. 2, wyd. S. Kuraś, Lublin 1973 (dalej cyt. ZDK), nr 322; Joannis Dlugossii Liber beneficiorum dioecesis Cracoviensis, wyd. A. Przeździecki, t. 2, Kraków 1864 (dalej cyt. DLB), s. 2-4 (1433 r.); Katalog kościoła N.P. Maryi w Krakowie, wyd. E. Długopolski, Teka Grona Konserwatorów Galicyi Zachodniej (dalej cyt. Teka), t. 6, Kraków 1916, nr 90 (1481 r.).

${ }^{22} Z D K 2$, nr 451, 455, LR, s. 132; B. K u m or, Dzieje diecezji krakowskiej do roku 1795, t. 2, Kraków 1999, s. 568; ZDK 2, nr 501, 505, 506. 
Tuż po 1254 r. miała prawdopodobnie miejsce fundacja ołtarza w benedyktyńskim kościele Św. Krzyża na Łysej Górze ${ }^{23}$, zaś w pierwszym dwudziestoleciu po kanonizacji doszło do fundacji kościołów klasztornych w Nowym Mieście Korczynie, Starym Sączu, oraz Lublinie. Były one dziełem księcia Bolesława Wstydliwego i jego małżonki św. Kingi, gorących propagatorów kultu biskupa męczennika ${ }^{24}$. Równie wczesną metryka legitymują się parafie w Czeladzi i Osieku. Czas powstania pierwszej określić można latami 1254-1260 ${ }^{25}$. W Osieku w latach 1255-1285 funkcjonował dwór książęcy oraz kaplica, ufundowana przez Bolesława Wstydliwego. Pod koniec XIII w. przy kaplicy erygowano parafię. Wezwanie zaś pojawia się już w 1278 r. na dokumencie wspomnianego księ$\mathrm{cia}^{26}$. Przed 1325 r. powstały także parafie w Racławicach, Oleksowie, Czemiernikach koło Kocka, Chlewiskach, Cerekwi Nowej, Żelechowie, Dobrzechowie, Zręcinie, Żembocinie, Sędziszowie i Szumsku ${ }^{27}$. Wspomnieć należy też o jednej z najstarszych parafii z wezwaniem złożonym, o Piotrawinie. Wiadomość o jej istnieniu znajduje się w opisie cudu św. Stanisława. Z kolei wezwanie - św. Tomasz Apostoł i Stanisław pojawiło się na dokumencie papieskim z 1402 r., nadającym kościołowi liczne odpusty. Także Długosz zarejestrował podwójny tytuł świątyni, pisząc jednocześnie, że pierwotnym jej patronem był św. Tomasz ${ }^{28}$. Nie sposób ustalić, kiedy dodano patrocinium. Zważywszy na silny w tym miejscu kult św. Stanisława (tutaj biskup miał dokonać cudu wskrzeszenia rycerza Piotra) mogło to się dokonać bezpośrednio po kanonizacji. Na lata panowania Kazimierza Wielkiego datowana jest kaplica zamkowa w Nowym Mieście Korczynie ${ }^{29}$, zaś w 1377 r. odnotowano kaplicę i prebendę żupną w Bochni. Wczesna metryka

${ }^{23}$ M. D e r w i c h, Benedyktyński klasztor Św. Krzyża na Lysej Górze w średniowieczu, Warszawa-Wrocław 1992, s. 183.

${ }^{24}$ DLB 3, Kraków 1864, s. 465-466; K. K a n t a k, Franciszkanie polscy, t. 1, Kraków 1937 , s. 31-32 (Korczyn); DLB 3, s. 465; B. K u m o r, Archidiakonat sadecki, „Archiwa, Biblioteki i Muzea Kościelne” (dalej cyt. „ABMK”), 9:1964, s. 130 (Stary Sącz); DLB 3, s. 458-459; J. K 1 o c zow sk i, Dominikanie polscy na Ślasku, Lublin 1956, s. 299-300. Pierwsza wzmianka o wezwaniu z 1409 r.; Zbiór dokumentów matopolskich, wyd. S. Kuraś i I. Sułkowska-Kuraś, cz. 5, Kraków-Wrocław 1970 (dalej cyt. ZDM), nr 1225 (Lublin).

${ }^{25}$ F. K i r y k, J. Raj ma n, Miasta ziemi siewierskiej [w:] Siewierz, Czeladź, Koziegłowy. Studia z dziejów księstwa siewierskiego, pod red. F. Kiryka, Katowice 1994, s. 308; DLB 2, s. 198.

${ }^{26} \mathrm{~K}$. M od z e l e w s k i, Organizacja gospodarcza państwa piastowskiego X-XIII w., Wroclaw 1975, s. 60; Monumenta Poloniae Vaticana, t. 1, wyd. J. Ptaśnik, Kraków 1913 (dalej cyt. $M V)$, s. $163 ; K D K 1, \mathrm{nr} 80, D L B 2$ 2, s. 321.

${ }^{27}$ MV. 1, passim; F. K i ry k, Urbanizacja Małopolski. Województwo sandomierskie XIII$-X V I$ w., Kielce 1994, s. 170-171 (Źelechów); BP 6, Rzym-Lublin 1998, nr 1425 (Zręcin); DLB 2, s. 518 (Chlewiska); $D L B$ 2, s. 548 (Oleksów); $D L B$ 2, s. 362 (Racławice); P. S z a fr a n, Rozwój średniowiecznej sieci parafialnej w Lubelskiem, Lublin 1958, s. 134 (Czemierniki); Kumor, Archidiakonat, s. 240 (Sędziszów); por. Szymański, jw., passim.

${ }^{28} \mathrm{~W}$ in c enty z K i e l c, Vita sancti Stanislai episcopi Cracoviensis. Vita minor, wyd. W. Kętrzyński, $M P H$, t. 4, Lwów 1884, s. 262; BP 3, Rzym-Lublin 1988, nr 766, DLB 2, s. $561-562$.

${ }^{29}$ DLB 2, s. 438; F. K i r y k, Urbanizacja..., s. 80-81. 
kaplicy jest jednak kwestionowana. $Z$ pewnościa przyjąć można, że istniała ona w czasach Długosza oraz w latach późniejszych ${ }^{30}$.

Kolejne świątynie parafialne dedykowane krakowskiemu męczennikowi powstały w Skrzyszowie $(1333 \text { r. })^{31}$, Wilczyskach $(1328-1335)^{32}$, Przybysławicach, Rakoszynie (około 1342 r.) ${ }^{33}$, Sromowcach Wyżnych, Łęcznej (około $1350)^{34}$, Jodłowej (przed 1359 r.) ${ }^{35}$, Dzierzkowicach, i Szyku $(1358-1374)^{36}$. Prawdopodobnie na koniec XIV w. możemy odnosić fundację kościoła św. Katarzyny i św. Stanisława w Kleczanowie. Pierwsza wzmianka o świątyni oraz wezwanie znajdują się w Liber beneficiorum. Jednakże patrocinium św. Katarzyny szczególnie popularne w XIV w. pozwala na przesunięcie jej metryki wstecz, prawdopodobnie na ostatnie ćwierćwiecze tego stulecia ${ }^{37}$. W ciagu XV i na początku XVI stulecia nastapiły fundacje dalszych światyń: w Sieklówce (1374-1402 r. $)^{38}$, Białej Górnej (1407 r. $)^{39}$, Ruszkowie $(1409 \text { r. })^{40}$, Zbuczynie (1385$-1418)^{41}$, Cmolasie $(1422 \text { r. })^{42}$, Rykach $(1374-1442)^{43}$, Biskupicach $(1444)^{44}$, Chruszczobrodzie $(1459)^{45}$ i Konieczkowej $(1460-1464)^{46}$. W 1470 r. z fundacji Jana Długosza wzniesiono nowy kościół w Szczepanowie, w miejscu narodzin

${ }^{30}$ Z. L e s z c zy ń s k a - S k r ę to w a, Bochnia [w:] Stownik historyczno-geograficzny województwa krakowskiego w średniowieczu, pod red. F. Sikory (dalej cyt. SHG), cz. I, z. 1, Wrocław 1980, s. 154-156, 164; DLB 2, s. 127.

3i B. K u m o r, Prepozylura tarnowska, „ABMK" 12:1966, s. 246-247; DLB 2, s. 309. Szerzej o kościele S. S a m b or s k i, Inwentarz kultu św. Stanisława ze Szczepanowa Biskupa i Męczennika w diecezji tarnowskiej, „Tarnowskie Studia Teologiczne” (dalej cyt. „TST”), 7:1979, s. 266.

${ }^{32} M V .1$, s. 370; DLB. 2, s. 255.

${ }^{33}$ MV.2, Kraków 1913, s. 190; BP 4, Rzym-Lublin 1992, nr 1671, oraz DLB 2, s. 497 (Przybysławice); $M V .2$, s. 180; S z y m án s ki, jw., s. 152 (Rakoszyn).

${ }^{34} M V .2$, s. 374-375; B. K u m o r, Archidiakonat, s. 190; por. DLB 2, s. 549.

${ }^{35}$ B. K u m or , Powstanie i rozwój, s. 528; S z y m ań s k i, jw., s. 144.

${ }^{36}$ MV. 9, wyd. S. Szczur, Kraków 1994; s. 3, S z y m a ń s k i, jw., s. 142, 154.

${ }^{37}$ DLB 2, s. 336; B. K u m or, Powstanie i rozwój, s. 464.

${ }^{38}$ B. K u m o r, Archidiakonat, s. 226. - Określa czas powstania parafii na 1489 r.; $B P 3$, nr 841 ; S z y m án sk i, jw., s. 153.

39 J. L a b e r s c h e k, Biała Wielka [w:] $S H G$, cz. I, z. 1, s. 65-66; DLB 2, s. 213.

${ }^{40} Z D M$ 5, nr 1226; DLB 2, s. 507.

${ }^{41}$ S. L i t a k, Formowanie sieci parafialnej w Eukowskim do końca XVI w., „Roczn. Hum.” 12:1964, z. 2, s. $105 ;$ S z y m ań s k i, jw., s. 157.

${ }^{42}$ W 1422 r. parafia nosiła wezwanie NMP, sś. Stanisława, Wojciecha. - ZDM 5, nr 1334. - W DLB 2, s. 270, oraz w aktach wizytacji, Szymański, jw., s. 141 występuje tytuł św. Wojciecha, posiadamy jednak wzmiankę z 1674 r. o ołtarzu głównym śś. Stanisława, Wojciecha. - J. Kracik, Konsekracje kościotów i ottarzy w diecezji krakowskiej w XVII-XVIII w., „NP.” 61:1984, s. 128.

${ }_{43}$ S. L i tak, Sieć parafialna archidiakonatu radomskiego $w$ okresie przedrozbiorowym, „Sprawozdania z Czynności Wydawniczej i Posiedzeń KUL", 9:1959, s. 106; S z y m a ń s k i, jw., s. 152.

${ }^{44} \mathrm{~S}$ z a fra n, Rozwój..., s. 126-127. Parafię utworzono przy drewnianym kościele, przeniesionym tutaj wraz z wystrojem wnętrza z Piotrawina. - DLB 3, s. 549; B. K u m o r, Dzieje diecezji, t. 1, Kraków 1998, s. 146.

${ }^{45}$ DLB 2, s. 194-195; F. S i ko r a, Chruszczobród [w:] SHG, cz. I, z. 2, Wrocław 1984, s. $378-379$.

${ }^{46}$ B. K u m o r, Archidiakonat, s. 253-254. Podaje jako pierwotne wezwanie: śs. Marii Magdaleny, Stanisława, Mikołaja. Długosz i źródła późniejsze odnotowują tylko tytuł św. Marii Magdaleny; S z y m a ń s k i, jw., s. 145. 
biskupa $^{47}$. Ostatnie parafie powstały w Batorzu (przed 1480 r. $)^{48}$, Łopusznej, Radziemicach (1480-1513) ${ }^{49}$, oraz Osobnicy (przed 1513 r. $)^{50}$.

Obszerne informacje o innych obiektach dedykowanych Świętemu pochodzą dopiero z XV w. Wśród nich spora grupe stanowia wzmianki o ołtarzach i kaplicach. Znajdowały się one w kościołach parafialnych: w Biechowie (1402 r.), Sieciechowicach (1410), Sandomierzu (1414 r. - parafia św. Piotra), Bytomiu (1427), Wieliczce (1432), Tczycy (1433), Wielogłowach (1467), Bieczu (1485), Zmigrodzie Nowym $(1523)^{51}$. Wspomnieć należy także o altarii, erygowanej w 1451 r. przez Jakuba z Dębna, kasztelana krakowskiego w kościele cysterskim w Mogile, oraz o oltarzu w kaplicy cmentarnej św. Barbary w Bieczu $(1473)^{52}$. Przed 1480 r. powstały także oratoria w Chotelu Zielonym i Paśmiechach ${ }^{53}$. Z kolei w miejscowości Pustynia koło Dębicy, jak pisze Długosz znajdował się drewniany kościółek pod wezwaniem św. Biskupa. W jego czasach był to ważny ośrodek pielgrzymkowy, przyciaggający na obydwa święta ku jego czci rzesze pątników. Sanktuarium funkcjonowało jeszcze na początku XVII stulecia ${ }^{54}$. Odnotować należy także dwie kaplice szpitalne, pierwszą w Mstowie, w granicznym odcinku diecezji, oraz w Opatowie. Interesujący nas tytuł pojawił się również na tablicy konsekracyjnej kościoła szpitalnego w Nowym Sączu, ufundowanego w $1510 \mathrm{r}^{55}$

W toku badań nad patrociniami natknąłem się ponadto na grupę kilku obiektów o niezwykle problematycznej chronologii wezwania. Jednym z nich jest parafia w Bielinach. Według Długosza światynia nosiła tytuł św. Wojciecha. Natomiast wizytacja Maciejowskiego z 1604 r. zanotowała potrójne patrocinium: NMP, śś. Wojciecha i Stanisława. Trudno określić, kiedy pojawiło się interesujace nas wezwanie. Zakładam, że Długosz podał niepełny tytuł. Pod koniec XVI w.

${ }^{47}$ DLB 2, s. 268-269. Szerzej M. Rożek, Kościelne fundacje Jana Dlugosza, „AC" $12: 1980$, s. 321.

${ }^{48} D L B 2$, s. 501, 576; S z y m a ń s k i, jw., s. 139.

${ }^{49}$ B. K u m o r, Archidiakonat, s. 178 (Lopuszna); W iśn i ow s k i, Materiały, s. 256; Sz y mań ski, jw., s. 152 (Radziemice).

${ }^{50}$ B. K u mor, Powstanie i rozwój, s. 529. Określa powstanie parafii na 1348 r., por. E. W iśn $\mathrm{n}$ o w s k i, Materiały do stanu liczebnego duchowieństwa $i$ stużby kościelnej $w$ diecezji krakowskiej w pierwszej potowie XVI w., „ABMK”, 18:1969, s. 238; S z y m a ń s k i, jw., s. 149.

${ }^{51} Z D M$ 5, nr 1161 (Biechów); ZDM 1, Kraków-Wrocław 1962, nr 286, ZDK 1, Lublin 1965 , nr 183 (Sieciechowice); ZDM 1, nr 307; LR, s. 398 (Sandomierz); BP 4, nr 2040 (Bytom); ZDM 2, nr 444, 445 (Wieliczka); ZDM 2, Kraków-Wroclaw, nr 471 (Tczyca); K u m o r, Archidiakonat, s. 136 (Wielogłowy); LR, s. 90 (Biecz); Archiwum Metropolitalne w Krakowie rkp. bez sygn.: Acta Episcopalia Cracoviensia (Ep.) 9. k. 24, (Żmigród). - Informacja o ostatnim ołtarzu pochodzi z kartoteki dr hab. J. Rajmana, za jej udostępnienie chcę w tym miejscu serdecznie podziękować.

${ }^{52}$ E. J a n ot a, Zbiór dokumentów klasztoru mogilskiego przy Krakowie, Kraków 1865, nr 148; F. S i k or a, Biecz [w:] SHG, cz. I, z.1, s. 80.

${ }_{54}^{53} D L B 2$, s. 382 (Chotelek Zielony); DLB 2, s. 179 (Paśmiechy).

${ }^{54}$ DLB 2, s. 262-263; K u m or, Archidiakonat, s. 144-146; S a m b or s k i, Inwentarz, s. 263; W. S z c z e r b a k, Zapomniane sanktuaria w diecezji tarnowskiej. Sanktuaria diecezji tarnowskiej, TST 9:1983, s. 463-465.

${ }^{5} D L B$ 3, s. 160-163; K u m o r, Dzieje, t. 1, s. 150-152 (Mstów); DLB 1, Kraków 1863, s. 591-592; K i r y k, Urbanizacja, s. 90-91 (Opatów); K u m o r, Archidiakonat, s. 109-110 (Nowy Sącz). 
większość ogólnych wezwań maryjnych została zastapiona bardziej szczegółowymi tajemnicami z życia Bogurodzicy ${ }^{56}$. Brak tego dookreślenia może wskazywać na wczesną metryke patrocinium maryjnego. Kościół mógł zatem początkowo mieć za patronkę NMP, lub też występować pod podwójnym tytułem: NMP i św. Wojciecha. W tym drugim przypadku wezwanie św. Stanisława, jako trzecie dodano po $1254 \mathrm{r}$. Inne możliwości interpretacyjne stwarza analogia z parafią w Cmolasie. Przypuszczać można, że oba tytuły (śś. Wojciecha i Stanisława) dodano do maryjnego w XV stuleciu. Innym kościołem $\mathrm{z}$ niepewnym tytułem sq̨ leżące $w$ archidiakonacie sandomierskim Wrzawy. Wezwanie parafii znamy od około 1600 r. Brzmiało ono następująco: NMP, śś. Wawrzyniec, Stanisław, Katarzyna. Analiza tytułu nasuwa wiele wątpliwości. Dwa pierwsze legitymują się wczesną metryka. Kiedy dodano pozostałe nie wiadomo. Możliwe, że stało się to w XIV stuleciu. W tym czasie bowiem tytuł św. Katarzyny cieszył się największą popularnością ${ }^{57}$. Analogia $\mathrm{z}$ tytułem parafii w Zbuczynie nie wyklucza jednak nieco późniejszej chronologii. Waţpliwości z chronologią odnieść można także do altarii. Niepewną metrykę ma ołtarz boczny w kościele parafialnym w Króżlowej, wzmiankowany dopiero w $1608 \mathrm{r}$. Znajdowała się w nim rzeźba św. Biskupa, która datowana jest na lata $1410-1420^{58}$. W tym czasie musiał powstać także i ołtarz, choć nie można tego stwierdzić $\mathrm{z}$ cała pewnością. Inny ołtarz znajdował się w parafii w Korzennej. Do naszych czasów zachował się tryptyk z przedstawieniem Legendy św. Stanisława. Obraz powstał w pierwszym dwudziestoleciu XVI w. i być może w tym okresie nastapiła erekcja altarii ${ }^{59}$.

Konstatując możemy zatem stwierdzić istnienie 74 obiektów dedykowanych św. Stanisławowi w średniowiecznej diecezji krakowskiej. W liczbie tej znalazło się aż 41 parafii. W 24 przypadkach św. Biskup był samodzielnym patronem (tabela 1), współpatronował zaś kolejnym 17 świątyniom (tabela 2).

${ }^{56} \mathrm{~J}$. R a w s k i, Wykazy świętopietrza $i$ dziesięciny papieskiej a najstarsze parafie $w$ archidiakonacie sandomierskim, „NP.” 13:1961, s. 59; DLB 2, s. 193; S z y m án s k i, jw., s. 128-129, 139.

${ }^{57}$ Jw., s. 157 , początek kultu św. Wawrzyńca na ziemiach polskich datowany jest na wiek XI, zaś najstarsze kościoły dedykowane temu świętemu spotykamy od przełomu XI-XII w., W. Sch e n k, Kult świętych w Polsce, "RTK”, 13:1966, z. 4, s. 81-82; K u mo r, Powstanie i rozwój, s. 464.

${ }^{58}$ S. Tomkowicz, Powiat grybowski, [w:] Teka, t. 1, Kraków 1900, s. 141; W. S z c z e r b a k, Motywy ikonograficzne postaci św. Stanisława Szczepanowskiego na podstawie zabytków z terenu diecezji tarnowskiej, „TST” 7:1979, s. 208.

${ }^{59} \mathrm{~S}$ a m bor s k i, Inwentarz, s. 252. 
Tabela 1. Parafie z tytułem głównym św. Stanisława

\begin{tabular}{|l|l|c|}
\hline \multicolumn{1}{|c|}{ Lokalizacja } & Przynależność kościelna & Pierwsza wzmianka o wezwaniu \\
\hline Osiek & arch. sandomierski & 1278 \\
\hline Przybysławice & arch. zawichojski & 1426 \\
\hline Żelechów & arch. radomski & 1447 \\
\hline Zręcin & dek. jasielski & 1459 \\
\hline Chlewiska & arch. radomski & 1470 \\
\hline Czeladź & dek. bytomski & 1470 \\
\hline Biskupice & arch. lubelski & 1470 \\
\hline Oleksów & arch. lubelski & 1470 \\
\hline Wilczyska & dek. bobowski & 1470 \\
\hline Racławice & arch. sandomierski & 1470 \\
\hline Czemierniki & arch. lubelski & 1565 \\
\hline Jodłowa & dek. biecki & 1595 \\
\hline Sieklowka & dek. jasielski & 1595 \\
\hline Osobnica & dek. jasielski & 1595 \\
\hline Dobrzechów & dek. pilzneński & 1595 \\
\hline Skrzyszów & dek. tarnowski & 1596 \\
\hline Sromowce & dek. nowotarski & 1596 \\
\hline Szumsko & prep. kielecka & 1597 \\
\hline Zembocin & dek. pleszowski & 1598 \\
\hline Radziemice & dek. wrocimowicki & 1598 \\
\hline Batorz & arch. zawichojski & 1598 \\
\hline Rakoszyn & dek. jédrzcjowski & 1598 \\
\hline Ryki & arch. radomski & 1600 \\
\hline Cerekiew Nowa & arch. radomski & 1600 \\
\hline & & \\
\hline
\end{tabular}

Tabela 2. Parafie z wezwaniem złożonym

\begin{tabular}{|l|l|l|c|}
\hline \multicolumn{1}{|c|}{ Lokalizacja } & \multicolumn{1}{|c|}{$\begin{array}{c}\text { Przynaleznośc } \\
\text { kościelna }\end{array}$} & \multicolumn{1}{|c|}{ Patrocinium } & $\begin{array}{c}\text { Pierwsza } \\
\text { wzmianka }\end{array}$ \\
\hline $\begin{array}{l}\text { Kraków- } \\
\text { Skałka }\end{array}$ & dek. krakowski & śs. Michal Archanioł, Stanisław & 1270 \\
\hline Piotrawin & arch. zawichojski & śs. Tomasz Apostol, Stanisław & 1402 \\
\hline Biała Górna & dek. lelowski & śs. Katarzyna, Małgorzata, Dorota, Jadwiga, Stanisław & 1407 \\
\hline Ruszków & arch. zawichojski & NMP, św. Stanisław & 1409 \\
\hline Cmolas & arch. sandomierski & NMP, śs. Stanisław, Wojciech & 1422 \\
\hline Chruszczobród & dek. bytomski & NMP, śs. Stanisław, Bernard & 1459 \\
\hline Konieczkowa & dek. pilzneński & śs. Maria Magdalena, Stanisław, Mikołaj & $1460-1464$ \\
\hline Kleczanoww & arch. sandomierski & śs. Katarzyna, Stanisław & 1470 \\
\hline Szczepanów & dek. wojnicki & śs. Maria Magdalena, Stanisław & 1470 \\
\hline Sędziszów & dek. pilzneński & Narodzenie NMP, św. Stanisław & 1595 \\
\hline Zbuczyn & arch. radomski & śs. Stanisław, Wawrzyniec, Katarzyna & 1595 \\
\hline Lęczna & arch. lubelski & śs. Maria Magdalena, Stanisław & 1596 \\
\hline Szyk & dek. dobczycki & śs. Barbara, Stanisław & 1596 \\
\hline Dzierzkowice & arch. zawichojski & śs. Maria Magdalena, Stanisław & 1598 \\
\hline Wrzawy & arch. sandomierski & NMP, śs. Wawrzyniec, Stanisław, Katarzyna & 1600 \\
\hline Bieliny & arch. sandomierski & NMP, śs. Wojciech, Stanisław & 1604 \\
\hline Lopuszna & dek. nowotarski & Sw. Trojjca, NMP, śs. Stanisław, Antoni & 1608 \\
\hline
\end{tabular}


Analiza zestawionego w powyższej tabeli materiału źródłowego wskazuje na fakt częstego występowania tytułu św. Stanisława z wezwaniami maryjnymi oraz śś. Katarzyny, Marii Magdaleny. Zważywszy na stosunkowo późny rozwój kultu Biskupa męczennika, liczba 41 parafii wskazuje na fakt dużej popularności patrocinium tego świętego. Należało ono do grupy najczęściej używanych ${ }^{60}$.

W przypadku dwóch parafii, oraz kościoła katedralnego z pewnością można wykazać fakt dodania patrocinium do już istniejącego. Hipotetycznie umieściłem w tabeli tytuły świątyń parafialnych we Wrzawach i Bielinach.

Tabela 3. Kościoły z wezwaniem dodanym

\begin{tabular}{|l|l|c|}
\hline \multicolumn{1}{|c|}{ Lokalizacja } & \multicolumn{1}{c|}{ Wezwanie pierwotne } & Pierwsza wzmianka o wezwaniu zlożonym \\
\hline Kraków-Katedra & św. Wacław & 1256 \\
\hline Kraków-Skałka & św. Michał Archanioł & 1270 \\
\hline Piotrawin & św. Tomasz Apostoł & 1402 \\
\hline Wrzawy & NMP, św. Wawrzyniec? & 1600 \\
\hline Bieliny & NMP, Wojciech? & 1604 \\
\hline
\end{tabular}

Odnotowałem ponadto istnienie 21 ołtarzy i kaplic. W tabeli pominięto oł$\operatorname{tarz} \mathrm{z}$ katedry wawelskiej, pierwotnie dedykowany św. Florianowi.

Tabela 4. Oltarze i kaplice

\begin{tabular}{|c|c|c|}
\hline Lokalizacja & Wezwanie & $\begin{array}{c}\text { Pierwsza } \\
\text { wzmianka }\end{array}$ \\
\hline Kraków-P. M. & Św. Trójca, śś. Stanisław, Wacław & 1383 \\
\hline Biechów & Św. Stanisław & 1402 \\
\hline Sieciechowice & św. Stanislaw & 1410 \\
\hline Sandomierz - św. Piotr & śs. Stanisław, Mikolaj & 1414 \\
\hline Bytom - NMP & św. Stanisław, Wszyscy Święci & 1427 \\
\hline Wieliczka-św. Klemens & $\begin{array}{l}\text { Ofiarowanie NMP, śs. Jan Chrzciciel, Jan Ewangelista, Stani- } \\
\text { sław, Agnieszka, Dorota Katarzyna, Małgorzata }\end{array}$ & 1432 \\
\hline Kraków-P.M. & $\begin{array}{l}\text { Nawiedzenie NMP, ss. Jan, Pawel, Leonard, Ludwik, Hipolit, } \\
\text { Władysław, Pantaleon, Stanisław, Klara, Agnieszka, Apolo- } \\
\text { nia, Łucja, Praxeda, Petronela }\end{array}$ & 1433 \\
\hline Tezyca & Wniebowzięcie NMP, śs. Stanislaw, Florian, Idzi & 1435 \\
\hline Kraków-św. Barbara & $\begin{array}{l}\text { Wniebowzięcie NMP, śs. Piotr, Pawel, Stanisław, Jan } \\
\text { Chrzciciel, Jan Ewangelista, Jerzy, Barbara, Katarzyna, Mał- } \\
\text { gorzata, Dorota, Agnieszka, Urszula, Elzbieta }\end{array}$ & 1443 \\
\hline Kraków-Sw. Trójca & ss. Katarzyna, Stanisław & 1447 \\
\hline Łysa Góra - Sw. Krzyz & ss. Michal, Stanisław, Łukasz Ewangelista, & 1451 \\
\hline $\begin{array}{l}\text { Mogiła-NMP, sw. Woj- } \\
\text { ciech }\end{array}$ & św. Stanisław & 1451 \\
\hline
\end{tabular}

${ }^{60}$ S z y ma ń s k i, jw., s. 102-106, 115-118. - Pod koniec XVI w. w diecezji krakowskiej najczęściej występującym wezwaniem był tytuł św. Mikołaja (74 kościoły). Patrocinium św. Stanisława (42) znalazło się na 9 pozycji. Natomiast wśród ,świętych polskich” tytuł ten zajmował miejsce pierwsze. Dla porównania patrocinium św. Wojciecha figurowało na drugiej pozycji (34). 


\begin{tabular}{|l|l|c|}
\hline Wielogłowy & Wniebowzięcie NMP, ss. Jan Chrzciciel, Stanisław & 1467 \\
\hline Biecz - sw. Barbara & $\begin{array}{l}\text { Wniebowzięcie NMP, ss. Zofia, Katarzyna, Dorota, Małgo- } \\
\text { rzata, Szczepan, Stanisław, Erazm, Walenty, Jan Ewangelista }\end{array}$ & 1473 \\
\hline Kraków - P. M. & $\begin{array}{l}\text { śś. Jan Chrzciciel, Antoni, Tomasz Apostoł, Grzegorz, Woj- } \\
\text { ciech, Stanisław, KJemens }\end{array}$ & 1481 \\
\hline Biecz - Boże Ciało & św. Stanisław & 1485 \\
\hline $\begin{array}{l}\text { Kraków - śs. Michał, Sta- } \\
\text { nisław }\end{array}$ & św. Stanisław & 1505 \\
\hline $\begin{array}{l}\text { Żmigród Nowy - śs. Piotr i } \\
\text { Paweł }\end{array}$ & św. Stanisław & 1523 \\
\hline Korzenna & św. Stanisław & 1608 \\
\hline Króżlowa & $\begin{array}{l}\text { śś. Stanisław, Mikołaj, 11000 Dziewic, Sebastian, Wszyscy } \\
\text { Swwięci }\end{array}$ & 1608 \\
\hline
\end{tabular}

Według ustaleń ks. Schenka ołtarze dedykowane Świętemu znajdowały się we wszystkich kościołach pod tym tytułem. W odniesieniu do kilkunastu parafii, pierwsze wzmianki pochodzą dopiero z XVII w. ${ }^{61}$ Zważywszy jednak na trwałość wezwania, mimo bardzo późnej metryki, zdecydowałem się na dołączenie grupy piętnastu ołtarzy (tab. 5) do podanej wyżej liczby obiektów. Łącznie zatem w diecezji krakowskiej ok. 1529 r. było przynajmniej 36 ołtarzy i kaplic.

Tabela 5. Ołtarze z kościołów parafialnych św. Stanisława

\begin{tabular}{|l|l|c|}
\hline \multicolumn{1}{|c|}{ Lokalizacja } & \multicolumn{1}{|c|}{ Wezwanie } & Pierwsza wzmianka \\
\hline Sędziszów & Ś́. Stanisław, Mikolaj, Wszyscy Święci & 1553 \\
\hline Cerekiew Nowa & sw. Stanisław & 1621 \\
\hline Wilczyska & sw. Stanisław & 1641 \\
\hline Ruszkow & św. Stanisław & 1659 \\
\hline Radziemice & sw. Stanisław & 1662 \\
\hline Chlewiska & sw. Stanisław & 1671 \\
\hline Cmolas & ś́. Stanisław, Wojciech & 1674 \\
\hline Szumsko & śs. Stanisław, Piotr i Pawel & 1678 \\
\hline Ryki & ś́. Jakub, Stanisław & 1679 \\
\hline Jodłowa & św. Stanisław & 1683 \\
\hline Dobrzechów & sw. Stanisław & 1683 \\
\hline Przybysławice & sww. Stanisław & 1741 \\
\hline Kleczanów & sw. Stanisław & 1741 \\
\hline Racławice & sw. Stanisław & 1742 \\
\hline Biała Górna & sw. Stanisław & 1746 \\
\hline
\end{tabular}

W ostatniej tabeli umieszczone zostały informacje o pozostałych jedenastu obiektach. Wśród nich znalazły się trzy szpitale, trzy kościoły klasztorne, dwie kaplice i wreszcie trzy kaplice domowe (oratoria).

${ }^{61}$ Informacje o oltarzach $\mathrm{z}$ tabeli 6 pochodzą z różnych akt konsekracji z lat 1621-1746. J. K r a c i k, Konsekracje, passim, w odniesieniu do Sędziszowa; K u m o r, Archidiakonat, s. 240. 
Tabela 6. Inne obiekty

\begin{tabular}{|c|c|c|c|}
\hline Lokalizacja & Nazwa & Wezwanie & $\begin{array}{c}\text { Pierwsza } \\
\text { wzmianka }\end{array}$ \\
\hline Lublin & Kosciół klasztorny & sw. Stanisław & 1409 \\
\hline Stary Sąz & Kościół klasztomy & sw. Stanisław & 1470 \\
\hline Nowe Miasto Korczyn & Kościoł klasztorny & Sw. Stanisław & 1470 \\
\hline Nowe Miasto Korczyn & Kaplica zamkowa & Sw. Trójca, św. Stanisław & 1470 \\
\hline Bochnia & Kaplica prebendarska & Ś. Stanisław & 1470 \\
\hline Pustynia & Oratorium & sw. Stanisław & 1470 \\
\hline Pasmiechy & Oratorium & \$w. Stanisław & 1470 \\
\hline Chotel Zielony & Oratorium & św. Stanisław & 1470 \\
\hline Opatów & Kaplica szpitalna & Św. Duch, św. Stanisław & 1470 \\
\hline Nowy Sącz & Kościół szpitalny & $\begin{array}{l}\text { Sś. Walenty, Piotr i Paweł, Stanisław, Fa- } \\
\text { bian i Sebastian, Aleksy, Jan Jałmużnik, } \\
\text { Anna, Małgorzata, Katarzyna, Urszula }\end{array}$ & 1510 \\
\hline Mstów & Kaplica szpitalna & sw. Stanislaw & 1598 \\
\hline
\end{tabular}

Dzięki badaniom stanu sieci kościelnej będziemy mogli teraz pokusić się o procentowe zestawienia obiektów dedykowanych patronowi Królestwa (wraz z wezwaniami złożonymi). Kościoły św. Stanisława w liczbie 48 stanowiły 4,8\% ogólnej sumy świątyń funkcjonujących około 1529 r. w biskupstwie krakowskim. Na $85 \overline{2}$ parafie dedykowano Świętemu aż 41 , co daje bỉisko $5 \%{ }^{62}$. W odniesieniu do kościołów klasztornych i szpitalnych współczynnik ten wynosił odpowiednio 8 i $6,5 \%$. Nie potrafimy za to, przy braku szczegółowych informacji przedstawić procentowego zestawienia ołtarzy i kaplic. Tylko przy hipotetycznym założeniu, że na jeden kościół przypadały cztery takie obiekty (łącznie 4012!), te z wezwaniem św. Biskupa (38) stanowić będą około 1\%. Liczba ta wydaje się stosunkowo niewielka. Jednakże dalsza kwerenda z pewnością przyniesie jej zwiększenie.

Uzyskany obraz wezwań odzwierciedlać może poszczególne fazy kultu św. Biskupa w diecezji krakowskiej. W pierwszym okresie, w którym św. Stanisław występował jako patron działań zjednoczeniowych zaobserwować można niebywały rozwój kultu. Świadectwem tego są liczne patrocinia. Po 1254 r. ufundowano aż 13 parafii dedykowanych Świętemu, poświęcono mu też kilka kościołów klasztornych. Po koronacji Władysława Łokietka (1320 r.) św. Stanisław stał się patronem państwa i jego monarchów. Nic więc dziwnego, że w czasach panowania Kazimierza Wielkiego, w okresie niebywałego rozwoju sieci kościelnej Biskupowi dedykowano kolejne parafie, w liczbie dziewięciu. Fundacje XV-wieczne pozostają w ścisłym związku z nowymi warunkami rozwoju kultu. Duże znaczenie miał statut biskupa Zbigniewa Oleśnickiego z 1436 r. włączający św. Stanisława obok śś. Wojciecha, Floriana, Wacława w poczet głównych patronów Królestwa Polskiego. Był on bowiem ukoronowaniem roli, jaką kult ten odgrywał dotychczas i zapowiedzią jego dalszego rozkwitu ${ }^{63}$. Dokonania Oleśnickiego znalazły godnego kontynuatora w osobie jego sekretarza i stronnika - Jana Dłu-

${ }^{62}$ Nie posiadamy zestawienia parafii z tytułem złożonym, wg Szymańskiego, jw., s. 111 i nn. pod koniec XVI w. zanotowano tylko 46 takich przypadków, co z pewnością jest liczbą zaniżoną.

${ }^{63}$ Starodawne prawa polskiego pomniki, wyd. A. Z. Helcel i inni, t. 4, Kraków 1875, s. 92. 
gosza. Największy polski dziejopis doby średniowiecza widział bowiem w patronie Polski i Krakowa ucieleśnienie ideału religijnego i patriotycznego ${ }^{64}$. Napisał nowy „Żywot" świętego, poświęcił mu także wiele miejsca na kartach swych dzieł. Szczególnie ważna jest działalność fundacyjna Długosza. Przypomnę, że dziejopis wybudował nowy kościół w Szczepanowie, sprowadził na Skałkę paulinów, chciał także założyć pustelniczy klasztor kartuzów. Instytucjonalne poparcie dla kultu św. Stanisława zaowocowało największą liczbą obiektów. W latach 1374-1470 powstało bowiem 13 parafii i 6 innych świątyń. Z tego czasu pochodzą także informacje o licznych ołtarzach. Po $1500 \mathrm{r}$. kult wchodzi w faze nie spotykanego dotąd rozkwitu, przejawiajacego się w bardzo licznych fundacjach artystycznych oraz twórczości poetyckiej. Niemałe znaczenie miała przypadająca w 1503 r. 250 rocznica kanonizacji. Odnotowane patrocinia (łacznie 8 lub 10 obiektów) nie są za to tak liczne, albowiem badania kończę na 1529 r.

Niniejszy szkic nie rości sobie pretensji do bycia synteza, obejmująca w sposób wyczerpujący wszystkie zagadnienia związane $\mathrm{z}$ wezwaniami św. Stanisława. Stanowi raczej wstęp do takiej monografii. Uzyskany obraz patrociniów nie jest bowiem kompletny. Jak już wielokrotnie wspominałem dalsze badania przyniosa z pewnością nowe informacje o kolejnych obiektach dedykowanych patronowi Królestwa. Prawdopodobnie też część hipotez i wniosków ulegnie weryfikacji. Nie sposób bowiem ustrzec się błędów podejmując badania nad problematyką tytułów kościelnych, która często prowadzi do sprzecznych ze sobą wniosków. Mam nadzieję, że przypadająca w tym roku rocznica tysiąclecia diecezji krakowskiej stanie się dobrą okazją do powstania prac poświęconych kultom świętym, a zwłaszcza jej głównym patronom. Nasza wiedza jest bowiem w wielu wypadkach fragmentaryczna, $i$ ten stan rzeczy choćby w niewielkim stopniu chciałem zmienić na kartach powyższego artykułu.

${ }^{64}$ M. K o c ze r s k a, Mentalność Jana Dlugosza w świetle jego twórczości, „Studia Źródłoznawcze", 15:1970, s. 109-140; U. B o r k o w s k a, Św. Stanistaw w koncepcji historii narodowej Jana Dlugosza, „Znak”, R. 31:1979, nr 298-299, s. 344-351. 